Haya: The Saudi Journal of Life Sciences

Abbreviated Key Title: Haya Saudi J Life Sci ISSN 2415-623X (Print) |ISSN 2415-6221 (Online) Scholars Middle East Publishers, Dubai, United Arab Emirates Journal homepage: https://saudijournals.com/sjls

Original Research Article

\title{
Phenotypic Correlation Coefficient Studies to Determine Interrelationships among Grain Yield and Related Characters in Maize
}

\author{
${ }^{1}$ Maize Breeding Sub Station, Chharrapani, Murree, Pakistan \\ ${ }^{2}$ Millets Research Station, Rawalpindi, Pakistan \\ ${ }^{3}$ Sugarcane Breeding Sub Station, Murree Pakistan
}

Naveed Kamal $^{{ }^{*}}$, Saeeda Khanum ${ }^{2}$, Muhammad Siddique ${ }^{2}$ and Muhammad Farooq Ahmed ${ }^{3}$

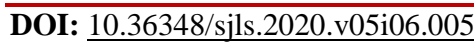

| Received: 30.05.2020 | Accepted: 22.06.2020 | Published: 26.06.2020

*Corresponding author: Naveed Kamal

\section{Abstract}

The objective of this study was to analyze genotypic and phenotypic variability, heritability and genetic advance for grain yield and different quantitative characters using five short duration temperate maize inbred lines in a $5 \times 5$ diallel cross. High genetic advance together with high heritability for grain yield, plant height and grains per row revealed the influence of additive gene effect in determining these characters. High heritability with low genetic advance for days to $50 \%$ tasseling, days to $50 \%$ silking and cob length indicated the influence of dominant and epistatic genes for these attributes. However correlation studies showed grain yield had negative correlation with days to $50 \%$ tasseling and days to $50 \%$ silking, while positive significant correlation with plant height. Whereas positive and highly significant correlation was found with cob length, number of rows per cob and number of grains per row revealing that these are the major yield contributing traits and can help in improving maize grain yield.

Keywords: Maize, genotypic variance, phenotypic variance, genetic advance, correlation.

Copyright @ 2020: This is an open-access article distributed under the terms of the Creative Commons Attribution license which permits unrestricted use, distribution, and reproduction in any medium for non-commercial use (NonCommercial, or CC-BY-NC) provided the original author and source are credited.

\section{INTRODUCTION}

Maize is the third most important cereal crop after wheat and rice. In Pakistan, maize is grown on an area of 1251.4 thousand hectares with total production of 5901.6 thousand tons with an average yield of 4716 kgha-1[1].

In Pakistan it is used as food and feed for human and livestock. Continuous efforts are being made to improve potential yield by maize breeders through genetic improvement of metric characters. Grain yield is a compound character and depends on other quantitative traits as components of the yield. Hence, the selection of superior genotypes based on yield as such would not be more valuable, but several yield attributes have to be handled together.

Improvement in yield potential would be more reliable, if indirect selection is made based on the traits correlated with yield. Thus, for rational improvement of yield and its components, the understanding of correlation of yield with different yield contributing characters is very crucial. This association should be at genotypic level by eliminating the environmental influence from the phenotypic values.
Therefore, accurate information pertaining to relationship of grain yield with other quantitative characters is useful. For this purpose breeders have successfully used correlation and heritability technique for this purpose [2].

Positive correlation of grain yield with most of attributes has been reported by [3]. While [4] have found negative correlation of grain yield with number of days to $50 \%$ tasseling and number of days to $50 \%$ silking.

The aim of correlation studies is primarily to know the suitability of various characters for indirect selection because selection of any particular trait may bring about undesirable changes in other associated characters [5].

Present study was therefore conducted to determine the relationship of grain yield $(\mathrm{Kg} / \mathrm{ha})$ with rest of the metric traits like number of days to $50 \%$ tasseling, number of days to $50 \%$ silking, plant height $(\mathrm{cm})$, cob length $(\mathrm{cm})$, number of rows per cob and number of grains per row. 


\section{MATERIALS AND METHODS}

The experimental material comprised of five short duration inbred lines of maize: Elp- 426, Elp-433, Elp-612, Elp-326 and Elp-780. All possible crosses (5x5 diallel) were made during spring 2018 at Maize Breeding Sub Station Chharrapani -Murree (Pakistan). Crosses harvested and were sown during next spring season in 2019. Data were recorded for grain yield ( $\mathrm{kg} / \mathrm{ha})$, number of days to $50 \%$ tasseling, number of days to $50 \%$ silking, plant height $(\mathrm{cm})$, cob length $(\mathrm{cm})$, number of rows per cob and number of grains per row.

The collected data was used for estimating analysis of variance [6] to find out the significance level among different genotypes. The genotypic and phenotypic coefficients of variation, broad sense heritability, genetic advance and simple correlation were calculated as suggested by [7].

\section{RESULTS AND DISCUSSION}

Highly significant differences for all the characters under study were found for all the traits studied indicating a considerable range of genetic variability among genotypes (Table 1). Genetic parameters including genotypic and phenotypic variances, genotypic and phenotypic coefficients of variability, heritability and genetic advance were also computed in (Table 2).

Phenotypic coefficients of variability were higher than genotypic coefficients of variability indicating the influence of environment upon the all recorded characters except for plant height which may be due to interaction of genotypes with environment. Similar results have been reported by [8].

High genetic advance together with high heritability for grain yield, plant height and grains per row revealed the influence of additive gene effect indicating that these characters can simply be improved by recurrent selection.

Genetic advance was higher for plant height, grains per row and grain yield which suggested that these results are in accordance with [9].

High heritability with low genetic advance for days to $50 \%$ tasseling, days to $50 \%$ silking and cob length indicated the influence of dominant and epistatic genes for these attributes.

However correlation studies (Table 3) showed grain yield had positive and highly significant correlation with cob length (0.6284), number of rows per cob (0.8720) and number of grains per row (0.9057) revealing that these are the major yield contributing traits in maize [10] and [2] also found number of rows per cob and number of grains per row major yield contributing traits. Similar results were also reported by $[11,4,3]$.
Negative correlation of grain yield with number of days to $50 \%$ tasseling and number of days to $50 \%$ silking is noteworthy (Table 3). [12] Also reported same results.

Remarkable difference in Phenotypic Coefficient of Variation (PCV) and Genotypic Coefficient of Variance (PCV) were observed for most of the traits (Table 2). PCV ranges from 4.96 to 407.48 and GCV ranges from 4.40 to 27.00. Among the studied traits, the high value for both PCV and GCV was estimated for plant height. Similarly, other traits number of grains per row, grain yield, cob length and number of grain rows per cob showed moderate PCV and GCV. In the same way low PCV and GCV were found in days to $50 \%$ tasseling, days to $50 \%$ silking. Sanjay Kumar et al. in his study also reported low value of PCV and GCV in days to tasseling and days to silking.

High estimates of broad sense heritability were observed for all the traits ranging from $72 \%$ for number of days to $50 \%$ silking to $97 \%$ for grain yield. The genetic advance (5\% selection intensity) was highest for grain yield (2702.07) followed by plant height (62.91) and number of grains per row (15.35) which indicated that maximum progress for improvement by selection is possible in these characters. While lowest genetic advance (2.82) was recorded for number of rows per cob.

Johnson, H.W., Robinson, H.F. et al. [13] Revealed that heritability alone is not very useful but heritability estimates along with genetic advance are important. High heritability coupled with high genetic advance was observed for plant height, grain yield and number of grains per row which indicated that these are governed by additive gene action and amenable for selection at phenotypic level.

These results are in close agreement with [14] who reported additive type of gene action for the traits like grain yield per plant, cob height, number of grains per row, plant height, cob length and number of rows per cob.

High heritability estimates accompanied by low genetic advance was observed for number of days to $50 \%$ tasseling, number of days to $50 \%$ silking and cob length indicating the influence of dominant and epistatic genes (non additive) for these characters. Thus it will be difficult to improve these characteristics through simple visual selection.

\section{CONCLUSION}

Accurate information pertaining to relationship of grain yield with other quantitative characters is useful. Correlation and heritability technique are studied for this purpose 
High heritability coupled with high genetic advance was observed for grain yield, plant height and number of grains per row which indicated that these characters are governed by additive gene action. These characters can simply be improved by recurrent selection and amenable for selection at phenotypic level.

High heritability estimates accompanied by low genetic advance was observed for days to $50 \%$ tasseling, days to $50 \%$ silking and cob length indicating the influence of dominant and epistatic genes (non additive) for these characters.
Heritability alone is not very useful but heritability estimates along with genetic advance are important. Thus it will be difficult to improve these characteristics through simple visual selection.

Positive and highly significant correlation was found with cob length (0.6284), number of rows per cob (0.8720) and number of grains per row (0.9057) revealing that these are the major yield contributing traits in maize.

Table-1: Mean square values of different quantitative characters in maize crosses

\begin{tabular}{|l|l|l|l|l|l|l|l|l|l|l|}
\hline S.O.V. & df & $\begin{array}{l}\text { Grain } \\
\text { Yield }\end{array}$ & $\begin{array}{l}\text { Number } \\
\text { of days } \\
\text { to 50\% } \\
\text { tasseling }\end{array}$ & $\begin{array}{l}\text { Number } \\
\text { of days } \\
\text { to 50\% } \\
\text { silking }\end{array}$ & $\begin{array}{l}\text { Plant } \\
\text { Height }\end{array}$ & $\begin{array}{l}\text { Cob } \\
\text { Height }\end{array}$ & $\begin{array}{l}\text { Cob } \\
\text { Girth }\end{array}$ & $\begin{array}{l}\text { Cob } \\
\text { Length }\end{array}$ & $\begin{array}{l}\text { Number } \\
\text { of Rows } \\
\text { per cob }\end{array}$ & $\begin{array}{l}\text { Number of } \\
\text { Grains per } \\
\text { row }\end{array}$ \\
\hline Reps & 1 & 10981 & 0.08 & 0.75 & 6.02 & 10.08 & 0.01 & 2.0833 & 1.33333 & 2.521 \\
\hline Treat & 24 & $3589331^{* *}$ & $21.53^{* *}$ & $23.76^{* *}$ & $1954.19^{* *}$ & $677.01 * *$ & $6.26^{* *}$ & $\begin{array}{l}16.9585 \\
* *\end{array}$ & $\begin{array}{l}5.33547 \\
* *\end{array}$ & $112.102^{* *}$ \\
\hline Error & 24 & 50361 & 2.77 & 3.84 & 30.14 & 14.12 & 0.04 & 0.3299 & 0.61111 & 0.332 \\
\hline
\end{tabular}

$*$ and $* *=$ Significant at 0.05 and 0.01 percent probability level, respectively.

Table-2: Genetic parameters for various quantitative characters in maize crosses

\begin{tabular}{|l|l|l|l|l|l|l|l|l|l|l|}
\hline $\begin{array}{l}\text { S. } \\
\text { No }\end{array}$ & Characters & Mean & $\begin{array}{l}\text { Standard } \\
\text { error }\end{array}$ & $\begin{array}{l}\text { Critical } \\
\text { difference }\end{array}$ & $\begin{array}{l}\text { Genetic } \\
\text { variance }\end{array}$ & $\begin{array}{l}\text { Phenotypic } \\
\text { variance }\end{array}$ & $\begin{array}{l}\text { GCV } \\
\text { \% }\end{array}$ & $\begin{array}{l}\text { PCV } \\
\text { \% }\end{array}$ & H \% & GA \\
\hline $\mathbf{1}$ & Grain Yield & 4925.1 & 158.68 & 333.228 & 1769485 & 1819846 & 27.00 & 27.39 & 97.23 & 2702.07 \\
\hline $\mathbf{2}$ & $\begin{array}{l}\text { Number of days } \\
\text { to 50\% } \\
\text { tasseling }\end{array}$ & 69.462 & 1.1763 & 2.47023 & 9.38 & 12.14 & 4.40 & 5.01 & 77.21 & 5.54 \\
\hline $\mathbf{3}$ & $\begin{array}{l}\text { Number of days } \\
\text { to 50\% silking }\end{array}$ & 74.885 & 1.3863 & 2.91123 & 9.95 & 13.80 & 4.54 & 4.96 & 72.15 & 5.52 \\
\hline $\mathbf{4}$ & Plant height & 209.59 & 3.8823 & 8.15283 & 962.02 & 992.16 & 41.41 & 15.02 & 96.96 & 62.91 \\
\hline $\mathbf{5}$ & Cob length & 15.912 & 0.4061 & 0.85281 & 8.3143 & 8.64 & 18.12 & 18.47 & 96.18 & 5.82 \\
\hline $\mathbf{6}$ & $\begin{array}{l}\text { Number of } \\
\text { rows per cob }\end{array}$ & 14.007 & 0.5528 & 1.16088 & 2.36 & 2.97 & 10.97 & 12.31 & 79.44 & 2.82 \\
\hline $\mathbf{7}$ & $\begin{array}{l}\text { Number of } \\
\text { grains per row }\end{array}$ & 31.331 & 0.4077 & 0.85617 & 55.88 & 56.21 & 23.86 & 407.48 & 99.40 & 15.35 \\
\hline
\end{tabular}

GCV = Genotypic Coefficient of Variability, PCV = Phenotypic Coefficient of Variability, H= Heritability and GA= Genetic Advance

Table-3: Estimates of phenotypic correlation coefficients in quantitative traits in maize crosses

\begin{tabular}{|l|l|l|l|l|l|l|l|}
\hline $\begin{array}{l}\text { S. } \\
\text { No }\end{array}$ & Characters & $\begin{array}{l}\text { Grain } \\
\text { Yield }\end{array}$ & $\begin{array}{l}\text { Number of } \\
\text { days to 50\% } \\
\text { tasseling }\end{array}$ & $\begin{array}{l}\text { Number of } \\
\text { days to 50\% } \\
\text { silking }\end{array}$ & $\begin{array}{l}\text { Plant } \\
\text { height }\end{array}$ & $\begin{array}{l}\text { Cob } \\
\text { length }\end{array}$ & $\begin{array}{l}\text { Number } \\
\text { of rows } \\
\text { per cob }\end{array}$ \\
\hline $\mathbf{1}$ & $\begin{array}{l}\text { Number of days to 50\% } \\
\text { tasseling }\end{array}$ & -0.0692 & & & & \\
\hline $\mathbf{2}$ & Number of days to 50\% silking & -0.1686 & $0.8910^{* *}$ & & & \\
\hline $\mathbf{3}$ & Plant height & 0.1642 & 0.2049 & 0.1210 & & & \\
\hline $\mathbf{4}$ & Cob length & $0.6284^{* *}$ & -0.049 & -0.0752 & -0.1963 & & \\
\hline $\mathbf{5}$ & Number of rows per cob & $0.8720^{* *}$ & -0.0512 & -0.1236 & 0.0704 & $0.7977^{* *}$ & \\
\hline $\mathbf{6}$ & Number of grains per row & $0.9057^{* *}$ & -0.0014 & -0.0717 & -0.0004 & $0.7490^{* *}$ & $0.8983^{* *}$ \\
\hline
\end{tabular}

$*$ and $* *=$ Significant at 0.05 and 0.01 percent probability level, respectively. 


\section{REFERENCES}

1. Anonymous. (2017-18). Agricultural Statistics of Pakistan. Government of Pakistan. Ministry of National Food Security and Research (Economic Wing).

2. Alaei, Y. (2012). Correlation analysis of corn Genotypes morphological traits. International Research Journal of Applied and Basic Sciences, 3(12), 2355-2357.

3. Wannows, A.A., Azzam, H. K., \& Ahmad, S. A.A. (2010). Genetic variances, heritability, correlation and path coefficient analysis in yellow maize crosses (Zea mays L.). Agriculture and Biology Journal of North America, 1(4), 630-637.

4. Ghimire, B., \& Timsina, D. (2015). Analysis of Yield and Yield Attributing Traits of Maize Genotypes in Chitwan, Nepal. World Journal of Agricultural Research, 3(5), 153-162.

5. Singh, P. (1998). Cotton Breeding. Kalyani Publishers, New Delhi, 191-211.

6. Steel, R.G.D., \& Torrie, J.H. (1980). Principles and procedures of statistics. A biological approach $2^{\text {nd }}$ ed., Mc.Graw Hill Inc., New York.

7. Singh, R.K., \& Chaudhary, B.D. (1985). Biometrical methods in quantitative genetic analysis. Kalyani Publishers, New Delhi.

8. Haq, M.I.U., Khanum, S., Siddique, M., \& Kamal, N. (2015). Correlation and heritability studies in pearl millet. International Journal of Biology and Biotechnology, 12(1), 81-83.
9. Rafiq, C.M., Rafique, M., Hussain, A., \& Altaf, M. (2010). Studies on heritability, correlation and path analysis in maize (Zea mays L.) Journal of Agricultural Research, 48(1), 35-38.

10. Singh, G., Kumar, R., \& Jasmine. (2017). Genetic parameters and character association study for yield traits in maize (Zea mays L.) Journal of Pharmacognosy and Phytochemistry, 6(5), 808813.

11. Alvi, M.B., Rafique, M., Tariq, M.S., Hussain, A., Mahmood, T., \& Sarwar, M. (2003). Character Association and Path Coefficient Analysis of Grain Yield and Yield Components Maize (Zea mays L.). Pakistan Journal of Biological Sciences, 6(2), 136138.

12. Malik, H. N., Malik, S. I., Hussain, M., Chughtai, S. U. R., \& Javed, H. I. (2005). Genetic correlation among various quantitative characters in maize (Zea mays L.) hybrids. Journal of Agriculture \& Social Sciences, 3, 262-265.

13. Johnson, H.W., Robinson, H.F., \& Comstok, R.E. (1955). Estimates of genetic and environmental variability in soybean. Agronomy Journal, 47, 314-318.

14. Maruthi, R. T., \& Rani, K. J. (2015). Genetic variability, heritability and genetic advance estimates in maize (Zea mays L.) inbred lines. Journal of Applied and Natural Science, 7(1), 149-154. 